\title{
Mobile Phone Terminal Education: the Trend of China's Education Development
}

\author{
Sun Yexia \\ Northeast Normal University \\ People Street No. 5268, Changchun, Jilin Province, China
}

\author{
Li Jing \\ Northeast Normal University \\ People Street No. 5268, Changchun, Jilin Province, China
}

\begin{abstract}
Education can enrich people's inner world, cultivate people's sentiment, and upgrade personal taste. In the era of Internet plus, mobile phone has become the largest carrier of China's education by virtue of its incomparable advantages. The scale of online education in China is also increasing with the third upgrading of consumption structure. From the demand side, the scale of online education users continues to grow. From the supply side, the number of education market financing is also increasing. Online education is a new direction for future education development, and it has great superiority that traditional education cannot compare with, such as flexible learning, real-time sharing, interesting interaction and so on.
\end{abstract}

Keywords-mobile phone terminal; education; traditional education; education investment

\section{INTRODUCTION}

China's smart phone penetration rate is higher than that of the globe. The data of the year of 2018 reveal that China's smart phone penetration rate has reached 68\% (the proportion of smart phones owned by adults), much higher than the global smart phone penetration rate of $43 \%$. The reason that the popularity of smart phone in China has gone up benefits from the rise of cost-effective Android phones in recent years. The phubbers who lower their heads to flood the cell phone screen all the time can be seen everywhere around us. The popularity and powerful functions of smart phone make it an new ideal learning terminal in the field of network education.

\section{THE IMPORTANCE OF EDUCATION IS OUTSTANDING}

The basis of labor-capital game is that there is a common but not completely consistent interest among the players. This Emphasis on education, especially quality education, has become the consensus of the whole society. It is necessary for quality education to promote people's all-round development, improve social cognitions, adapt to social interactions, and master the skills of production and livelihood in society. Education is an important part of human self-development and improvement. Quality education needs to attach importance to talent education. Meanwhile, talent education can enrich people's inner world, cultivate people's sentiment, upgrade personal taste, and even there is research indicating that it is also beneficial to intellectual development. Most families value talent education, taking into account the cultivation of children's comprehensive quality, however, some families just want to get extra credit for going to college, believing it's a "shortcut" to get into a famous university. In some places, some policies have been introduced to link art and sport achievements with further studies, and which have also promoted the more important and extensive development of talent education. The transformation and development of education is closely related to information technology. In recent years, with the rapid development of Internet technology, colleges and universities around the world have established distance education based on Internet technology and multimedia technology. With the acceleration of knowledge update and social competition, the education content update is also greatly accelerated. In order to adapt to this change, it is inevitable to have lifelong education. Only in lifelong education can people achieve all-round development.

The goal of human development proposed by Marx on the theory of people's all-round development is the highest goal of quality education. At the height of the development of human society, Marx raised the issue of people's all-round development. The quality education issue studied and discussed in the current educational circles has not surpassed Marx's theory of people's all-round development. Marx pointed out that by virtue of social production, it was not only possible to ensure that all members of society had a prosperous and increasingly abundant material life, but also to guarantee the full and free development and utilization of their physical strength and mentality. The purpose of social production is to create conditions to constantly transform people's own, so that people's connotations can be continuously enriched and perfected and people's individuality and group can be fully developed. That is to say, the all-round development of human beings is not only the full and free development of physical strength and mentality, but also the full and free development of human nature; it is not the all-round development of a few people, but the all-round development of all members of society; it is not only the allround development of individuals, but also the coordinated and unified development of individuals and society. This goal is the highest goal of today's quality education. In Capital, Marx said: "In the future, for all children who have reached a certain age, education is a combination of productive labor with moral education and physical education. It is not only a process to improve social production, but also the only way to bring up the humans of all-round development.”

As this point, Marx organically unites the social purpose of improving social production by education with the individual purpose of people's all-round development. Marx's theory of people's all-round development reveals the law of people's all-round development in the unity of human development and social development. Today, the construction of our quality 
education goal should be built closely around Marx's goal of people's all-round development, so as to achieve the coordinated and unified development of people and society.

\section{INTERNET EDUCATION IS STANDING OUT AND EDUCATION IS} IN GREAT DEMAND

In the third currently on-going upgrading of consumption structure, the fastest growth is the consumption in education. The data show that an average of 2.3 online education companies were established in China every day in 2013. The scale of China's online education market has increased from 15 billion Yuan in 2004 to 83.974 billion Yuan in 2013, with an average annual compound growth rate of $22.5 \%$. In 2017, the scale of China's online education market is expected to be close to 300 billion Yuan. As one of the sub-industries of education training, Internet education has developed rapidly. It is known as the third generation of distance education form following the first generation of correspondence teaching and the second generation of satellite TV broadcasting teaching. Internet education is a new educational model that develops from the network education and achieves educational goals through various channels of the Internet, in which the mainstay includes the course content producer, the platform resource integrator, the tool product provider and the technical equipment provider. However, its content is far better than online education. It not only includes online classrooms, but also concludes the teaching and learning resources integration platform for the purpose of flow rate, tools for assisting learning (platform or APP), and equipment and technology required to achieve Internet education.

From the perspective of demand, the number of online education users has also been increasing rapidly in recent years. Since 2010, the scale of online education users in China has maintained a high growth rate of more than 10\%. By 2014, the number of online education users was 77.696 million, a year-on-year increase of $16.03 \%$. In June 2016, the scale of online education users in China reached 118 million. The scale of online education users is expected to continue to grow, and with the continuous expansion of online education user groups, the market size of online education will be further expanded. The number of mobile phone online education users was 69.87 million, an increase of 16.84 million compared with the end of 2015 , with a growth rate of $31.8 \%$. The mobile phone online education utilization rate was $10.6 \%$, an increase of 2 percentage points compared with the end of 2015.

From the perspective of supply, domestic investment in the Internet education industry has always been in a hot state since 2013. According to statistics, in 2014, the investment scale of Internet education industry in China reached 18 billion Yuan, of which BAT investment amounted to 1.5 billion US dollars. In 2015, K12 online education institution Crazy Teacher announced a \$20 million financing from Tencent. Moreover, there were also much other large investment and financing. The education industry's primary market financing experienced a slight cold in 2016 and began to pick up in 2017. In 2018, the financing environment of the primary market continued to improve, with 182 cases just in the first half of 2018, and there was strong financing heat in the middle and late stage, increased large-scale financing and popular high- quality projects. In the meanwhile, the disclosed financing amount attained 15.273 billion Yuan, close to the total amount of 18 billion Yuan in the whole of last year.

TABLE I. $\quad$ EDUCATION INDUST RY FINANCING TIMES OF 2011-2018

\begin{tabular}{|c|c|c|c|c|c|c|c|}
\hline 2011 & 2012 & 2013 & 2014 & 2015 & 2016 & 2017 & First half year of 2018 \\
\hline 53 & 55 & 102 & 268 & 489 & 350 & 404 & 182 \\
\hline
\end{tabular}

From the perspective of the development of online education in China, there is a high degree of investment enthusiasm in the field of online education, and a large amount of capital enters online education. Generally speaking, K12 online education, online foreign language training, online vocational education and other subdivisions have become the main driving force for the growth of China's online education market.

As far as the development stage of China's Internet education industry is concerned, its development is still in its infancy. The In-depth Research Report on China Internet plus Education Industry Business Model Innovation and Investment Opportunity released by forward-looking industry research institute shows that the scale of China's Internet education market reached 99.8 billion Yuan in 2014, a year-on-year growth rate of $18.84 \%$. Vocational education, language training and degree education are the main driving forces for the rapid growth of the market scale, accounting for more than $75 \%$ of the market scale. With the continuous expansion of the Internet education user groups, the Internet education market will have greater development. All subdivisions of Internet education have maintained a relatively fast growth level. Among them, primary and secondary school online education, enterprise E-learning and online language training have a relatively rapid development, the market growth has a better performance, and the capital fever is also higher. At the same time, the preschool education has slowed down due to the previous low base. However, with the full liberalization of the second child, preschool education is expected to get back to the rapid growth track. In addition, other subdivisions, like higher degree online education, still have market potential need to be further tapped.

\section{THE MODE OF MOBILE TERMINAL EDUCATION}

\section{A. MOOC}

The enthusiasm and upsurge of the construction and promotion of the "MOOC" in the field of education in the world, including China, are also seeing a trend towards full swing. The "MOOC" is in particular widespread and profoundly applied into the fields of higher education, adult education and basic education. The reason why the "MOOC" can be accepted and used by a large number of users in a short period of time is inseparable from its distinctive features. With the help of the Internet, the "MOOC" has built a convenient bridge between learners and lecturers all over the world, and realized the connection between teaching and learning beyond the bounds of space and time. The emergence of the "MOOC" is called the biggest innovation in education. The global network transmission of the "MOOC" can make its coverage 
be possible to achieve scale. On the other hand, the rapid development of the mobile Internet has also been deeply affecting the online education industry. The competition between APP and PC in online education is a trend. In addition, the introduction of the "MOOC" APP makes it more prominent in the field of education.

\section{B. Micro course}

The concept of micro course originated in the United States, and its purpose is to refine the original tens of minutes or one-hour course into a 5 to 10 minutes micro-video course, providing learners with mobile and fragmented online learning opportunities. The micro course takes the short and concise video as the carrier, highlights the key and difficult points of the classroom instruction. In the meanwhile, there are prominent themes and small resource occupied space in micro course, which are very suitable for use on mobile terminals. With the development of 3G/4G communication network technology and the explosion of smart mobile terminal users, micro course, as a ubiquitous learning mode, has been in a stage of blowout development in China in recent years. The micro course has created a teaching environment based on courseware fragments, providing opportunities for learners' personalized and efficient self-learning through semistructured and thematic curriculum resources. At the same time, the micro course is a useful supplement to the traditional classroom instruction mode, with its advantages of distinctive theme, rich type, high efficiency, time saving and practicality, and it can meet the objective situation where adult learners' learning time is in fragmentation.

\section{Flipped classroom}

Faced with the instructional needs of interactive teaching and in-depth learning, the combination of mobile terminal APP and flipped classroom is a new direction of education reform. The flipped classroom reconstructs the learning process, and the students fully master the decision-making power of learning. During the class time, the teacher is no longer the docent of the teaching content, and the students have completed the information transmission process of the teaching content through the teaching video and online tutoring before the class.

The mobile APP-based education flipped classroom mode can make the teaching resources more open. Through the integration and utilization of different high-quality teaching resources, students can acquire knowledge points suitable for their own level and content in the open mobile network. Mobile APP extends the learning time and space, so knowledge can be learned in any place and fragmented time. Compared with traditional classroom instruction, abundant online learning resources such as videos, audios, pictures and texts can arouse learners' learning enthusiasm and initiative. At the same time, with the help of the mobile APP platform, teachers can understand the learning situation of each learner in a timely and accurate manner, and teachers can work out a personalized learning plan that varies with each individual to improve the teaching quality.
V. THE AdVANTAges OF MOBILE TERMinAl EDUCATION ARE OF PROMINENCE

In the first half of 2016, the proportion of Internet users using mobile phones and TVs was significantly higher than that of the end of 2015. As of June 2016, the proportion of Internet users using mobile phones in China reached 92.5\%, an increase of 2.4 percentage points from the end of 2015. With the rapid development of the smart TV industry, as a home network device, TV has been further revealed its entertainment function. The proportion of those who use TV to surf the Internet is $21.1 \%$, an increase of 3.2 percentage points from the end of 2015. At the same time, there are $64.6 \%$, 38.5\% and $30.6 \%$ of Internet users surfing the Internet with desktop computers, laptops and tablets, respectively decreases of $3.1,0.2$ and 0.9 percentage points from the end of 2015.

The mobile terminal itself has incomparable advantages and is easy to be carried. The cellphone can use the mobile network, and the IPAD and other devices can use WIFI. At present, free WIFI is a standard configuration in major shopping malls, hotels and other places. The mobile terminal can be flexibly accessed into the network, and it can be frequently used at any time such as waiting for a bus or a taxi, shopping or relaxing in a mall, waiting for food in a restaurant, and before going to bed. As a result, the usage frequency of a mobile terminal is much higher than that of a PC. The convenience of the mobile terminal enables users to learn at fragmented time, and the learning efficiency can be improved.

College students have the most leisure time and selfcontrolling time. The questionnaire survey on education APP using status and habit of college students showed that more than half of the students began to use education APPs at college, and $94.07 \%$ of the students who had not used education APPs expressed their willingness to use. The number of students who knew about education APPs accounted for $77.97 \%$, the proportion of students who downloaded educational APPs on mobile phones was $82.2 \%$, and the proportion of learning tools in the downloaded APPs was up to $83.9 \%$. The principal ways that college students knew APPs were the discovery by themselves and the introduction from their classmates and friends, accounting for $59.32 \%$ and $28.81 \%$ respectively.

No matter which stage students are in, they have gradually developed the paying habit of high-quality content. For example, the most important form of teaching in education APPs is video. Due to the nurturance of user's payment habit, video users have a large room to increase their value-added consumption potential. Since 2015, drove by many factors, the number of paid users of video websites has rapidly, and the proportion of membership income has added in overall revenue. At present, the method that the mainstream video websites attract users to pay is mainly by means of differentiated arrangement of popular programs. In the future, more value-added consumption methods can be explored on the basis of the big data's deep operation and demand exploitation for member users. Besides, the prosperity of live channels/live products and the self-channels of the video websites will promote the development of value-added service 
mode and enrich the revenue source of the video platforms. The operation mode of this kind of video can be fully used for reference in that of the mobile terminal education APP. In addition, the progress of the current video website content is also an important reference for the mobile terminal education APP in the future. At present, the competition on copyright purchases of major video websites is slowing down, and the self-made content is developing towards premiumising and differentiation. With the maturity of the network video industry chain, the mainstream video platforms have basically stepped into the development and production of upstream content, and their professional operations have significantly improved the level of self-made content. At present, the number of self-made programs on mainstream video platforms presents the trend of surpassing the copyright purchases. On the one hand, major video websites maintain the investment in super IP and pure web variety shows. On the other hand, the content construction in vertical areas such as sport, finance, comics and music are enhanced, and the differentiated content platforms are created. In a word, personalization and differentiation are significant advantages for future competition.

\section{CONCLUSION}

With the acceleration of knowledge renewal and the intensification of social competition, the speed of educational content renewal is also accelerating. In order to adapt to this change, it is necessary to have lifelong education. Mobile terminal education has great superiorities that traditional education cannot compare with, such as flexible learning, realtime sharing and interesting interaction, and it is the most suitable platform for lifelong education. The three forms of mobile terminal education can be easily recognized by the young, which provides a new direction for the development of online education enterprises. The data also shows that China's mobile terminal education advantages are of prominence.

\section{REFERENCE}

[1] Marx: Capital, People's Publishing House, 2004.

[2] Shao Changhai: Research on Mobile Phone Learning Education Design Mode, China Management Informationization, 2015 (10).

[3] Zhang Shuming: Marx's Theory on All-round Development of Human Beings and Its Educational Significance, Theory Monthly, 2007 (7). 